\title{
Towards a Unified Definition of Web Accessibility
}

\author{
Helen Petrie \\ Human Computer Interaction \\ Research Group, University of York, \\ Department of Computer Science \\ Deramore Lane, Heslington East \\ York, YO10 5GH, UK \\ Helen.Petrie@york.ac.uk
}

\author{
Andreas Savva \\ Human Computer Interaction \\ Research Group, University of York, \\ Department of Computer Science \\ Deramore Lane, Heslington East \\ York, YO10 5GH, UK \\ as1517@york.ac.uk
}

\author{
Christopher Power \\ Human Computer Interaction \\ Research Group, University of York, \\ Department of Computer Science \\ Deramore Lane, Heslington East \\ York, YO10 5GH, UK \\ Christopher.Power@york.ac.uk
}

\begin{abstract}
To better understand what researchers and practitioners consider to be the key components of the definition of web accessibility and to propose a unified definition of web accessibility, we conducted an analysis of 50 definitions of web accessibility. The definitions were drawn from a range of books, papers, standards, guidelines and online sources, aimed at both practitioners and researchers, from the across the time period of web accessibility work, from 1996 to 2014 and from authors in 21 different countries. The analysis extracted six core concepts that are used in many definitions, which are incorporated into a unified definition of web accessibility as "all people, particularly disabled and older people, can use websites in a range of contexts of use, including mainstream and assistive technologies; to achieve this, websites need to be designed and developed to support usability across these contexts".
\end{abstract}

\section{Categories and Subject Descriptors}

H.3.5 [Online information services]: Web-based services. K.4.2 [Social Issues]: Assistive technologies for persons with disabilities.

\section{General Terms}

Design, Human Factors.

\section{Keywords}

Web accessibility, people with disabilities, older people, practitioners and researchers in web accessibility

\section{INTRODUCTION}

Making the web accessible and usable by people with disabilities and older people has been a topic of considerable importance since early in its development $[1,2,3,4]$. However, there is no widely agreed definition of web accessibility, although there are several well-known statements, such as Berners-Lee's [5] succinct and clear statement that "it is critical that the Web be usable by anyone, regardless of individual capabilities and disabilities". In

Permission to make digital or hard copies of all or part of this work for personal or classroom use is granted without fee provided that copies are not made or distributed for profit or commercial advantage and that copies bear this notice and the full citation on the first page. Copyrights for components of this work owned by others than ACM must be honored. Abstracting with credit is permitted. To copy otherwise, or republish, to post on servers or to redistribute to lists, requires prior specific permission and/or a fee. Request permissions from Permissions@acm.org.

W4A '15, May 18 - 20, 2015, Florence, Italy

Copyright is held by the owner/author(s). Publication rights licensed to ACM.

ACM 978-1-4503-3342-9/15/05 ..\$15.00

DOI: http://dx.doi.org/10.1145/2745555.2746653 addition, the relationship between web accessibility and web usability is unclear and subject to some debate $[6,7,8]$.

Is it a problem that there is no widely agreed and used definition? Web accessibility is a complex and multi-component concept, which perhaps needs a range of definitions. However, from a scientific point of view, having a complete, unified definition of web accessibility would provide a basis for guiding empirical studies that explore the relationship between the components of the concept and the relationship of web accessibility to other concepts such as web usability. As a research community, we should be able to speak with certainty about what we are varying and what we are controlling for in our studies in relation to a unified definition, making studies more comparable and making clearer what is new knowledge. From the point of view of understanding the accumulated knowledge about web accessibility, a unified definition is needed in order to judge progress and identify gaps in our existing knowledge with reference to each of the different components of the concept. From a design point of view, in order to move web design and assistive technologies forward, designers and developers require a definition that encompasses all components of web accessibility. Without such a definition, designers and developers run the risk of having only a portion of the picture of what will impact disabled and older users in their interactions with the web. Otherwise important aspects may be left out of design. An agreed and complete definition would allow designers and developers to interrogate their work in relation to the different components, allowing them to be more critical of their designs in a more structured way.

Petrie and Kheir [7] addressed the problem of the definition conceptually and more recently Yesilada et al [8] undertook a survey on this topic. The authors of this latter paper asked a wide range of people involved and interested in web accessibility for their opinions and comments on five different definitions of web accessibility [6], [9, 10, 11, 12]. From a large number of respondents (they obtained 300 valid responses), they found that the most popular definition, chosen by $45 \%$ of respondents, was the definition given by the WAI [9] "web accessibility means that people with disabilities can use the Web. More specifically, Web accessibility means that people with disabilities can perceive, understand, navigate and interact with the Web, and that they can contribute to the Web". The second most popular definition, chosen by $32 \%$ of respondents, was from the Section 508 Amendment of the Rehabilitation Act in the USA [10] that "technology is accessible if it can be used as effectively by people with disabilities as those without". Preference for these two definitions was regardless of respondent age, country, work sector or profession. There was a stronger preference amongst respondents with a scientific/technical education for the first definition, but this was not tested statistically. While these results 
are interesting, it is not clear whether there is a familiarity factor at work - respondents may have been choosing the definitions they have seen most often. This is hinted at by the fact that people with scientific/technical educations chose the WAI definition more frequently, as it may well be that they have been more exposed to this definition. So it would have been useful to ask respondents which definitions they were familiar with.

In this paper we have decided to take a different, yet complementary, approach to that taken by Yesilada et al [8]. We have gathered many different definitions from the extensive literature on web accessibility and conducted a conceptual analysis of these definitions, in order to better understand what are considered the key components of the definition of web accessibility by the practitioner and research community and to propose a unified definition of web accessibility, drawing on all these components.

\section{METHOD}

As part of a larger project, a comprehensive web search was conducted in four digital libraries (Google Scholar, ACM Digital Library, IEEE Xplore, Science Direct). Search terms were "website/web site/web-site/webpage/web page/web-page accessibility" and "accessibility of website/web site/website/webpage/web page/web-page". No time period was set for the search, although of course, all the papers returned were published after the invention of the Web in 1989, and most papers were published after 1995 when interest in web accessibility substantially increased.

From this pool of papers we then searched for papers which provided definitions of web accessibility. This has been achieved by searching for possible introductions of definitions with terms such as "web accessibility is ...", "web accessibility means ...", "web accessibility aims ..." "definition of web accessibility ..." and by manually skimming the Introduction and Background sections of papers.

This search has so far produced a total of 75 papers with definitions, four from guidelines and standards documents $[9,10$, $11,12]$ and 71 from published papers, books and online documents. All definitions are definitions of web accessibility in general, although some of the documents are about specific aspects of the concept, for example web accessibility for a particular user group. Papers which provided definitions about a particular aspect of web accessibility when not included in the corpus.

For this paper and as an initial test of our proposed approach, a sample of 50 definitions was analysed. This sample was taken from across the time period of web accessibility work, from 1996 to 2014, and included four guidelines and standards documents, 37 academic papers, three online documents and six books for practitioners. We deliberately sought to include materials used by practitioners as well as researchers, hence the inclusion of books for practitioners and online documents. In addition, we deliberately sought to represent an international view of web accessibility, so the definitions are proposed by authors from 21 different countries, including all continents apart from Africa (although one paper did investigate the accessibility of websites in Africa [13]): Asia (Bangladesh India, Japan, Korea, Malaysia, Sri Lanka, Taiwan), Australasia/Oceania (Australia), Europe (Cyprus, France, Germany, Italy, Portugal, Romania, Spain and the UK) and the Americas (Argentina, Brazil, Canada, Ecuador, and the USA). The definitions are listed in the Appendix, with the sources, countries of the authors, and the antecedents of the definition and the authors understanding of web accessibility in general.

The analysis of the definitions was conducted in two phases. Firstly, all relevant content words were extracted from the definitions; grammatical variations (operate, operability) and close synonyms (anyone, all users) were grouped together. Secondly, all the content words were grouped into concepts. All these analyses were checked by at least two of the authors, and any errors or omissions corrected. Six concepts emerged from the analysis, these are summarized in Table 1.

The analysis of the antecedents was conducted as follows: for antecedents to the definitions, only sources explicitly referred to in presenting the definition were noted. For "general antecedents", the reference list of the document was studied and all references cited which were known to offer a definition of web accessibility were noted. We realize this second analysis is currently incomplete, as we have not been able to check every reference to see whether it offered a definition. This analysis is continuing, but some comments are made below on the results so far.

\section{RESULTS}

Table 1 shows the number of definitions that included the six different concepts, including the number of important specific examples within the concepts. For example, 49 of the 50 definitions referred to groups of users or the characteristics of users, whether users with disabilities (35 definitions), or all users or as many users as possible (12 definitions). Interestingly, only three of the definitions referred explicitly to older users, although this user group is often considered within the scope of web

Table 1. Concepts used in the 50 definitions of web accessibility

\begin{tabular}{|l|l|c|}
\hline \multicolumn{1}{|c|}{ Concept } & \multicolumn{1}{|c|}{$\begin{array}{c}\text { Explanation, examples } \\
\text { (with frequencies) }\end{array}$} & $\begin{array}{c}\text { Number of } \\
\text { definitions } \\
\text { mentioning }\end{array}$ \\
\hline $\begin{array}{l}\text { Groups of } \\
\text { users, } \\
\text { characteristics, } \\
\text { needs of users }\end{array}$ & $\begin{array}{l}\text { with disabilities (35), all } \\
\text { users/as many as possible } \\
\text { (12), characteristics (12), } \\
\text { specific disabled groups (4) }\end{array}$ & $49(98 \%)$ \\
\hline $\begin{array}{l}\text { What users } \\
\text { should be able } \\
\text { to do }\end{array}$ & $\begin{array}{l}\text { access (20), use (15), interact } \\
\text { (9), navigate (7), understand } \\
\text { (5), perceive (4), available } \\
\text { (3), achieve goals (2), } \\
\text { contribute (2), } \\
\text { benefit/get/perform/reach/ } \\
\text { visit (1 each) }\end{array}$ & $44(88 \%)$ \\
\hline $\begin{array}{l}\text { Technologies } \\
\text { used }\end{array}$ & $\begin{array}{l}\text { mainstream technologies (10), } \\
\text { assistive technologies (5) }\end{array}$ & $15(30 \%)$ \\
\hline $\begin{array}{l}\text { Characteristics } \\
\text { of the website }\end{array}$ & $\begin{array}{l}\text { usability or aspects of } \\
\text { usability (efficiency, } \\
\text { effectiveness etc) }\end{array}$ & $15(30 \%)$ \\
\hline $\begin{array}{l}\text { Design and } \\
\text { development of } \\
\text { the website }\end{array}$ & $\begin{array}{l}\text { design (5), standards/ } \\
\text { guidelines (3) }\end{array}$ & $12(24 \%)$ \\
\hline $\begin{array}{l}\text { Characteristics } \\
\text { of the situations } \\
\text { of use }\end{array}$ & $\begin{array}{l}\text { in specified contexts of use } \\
\text { (3), in environmental } \\
\text { constraints (3) }\end{array}$ & $7(14 \%)$ \\
\hline
\end{tabular}




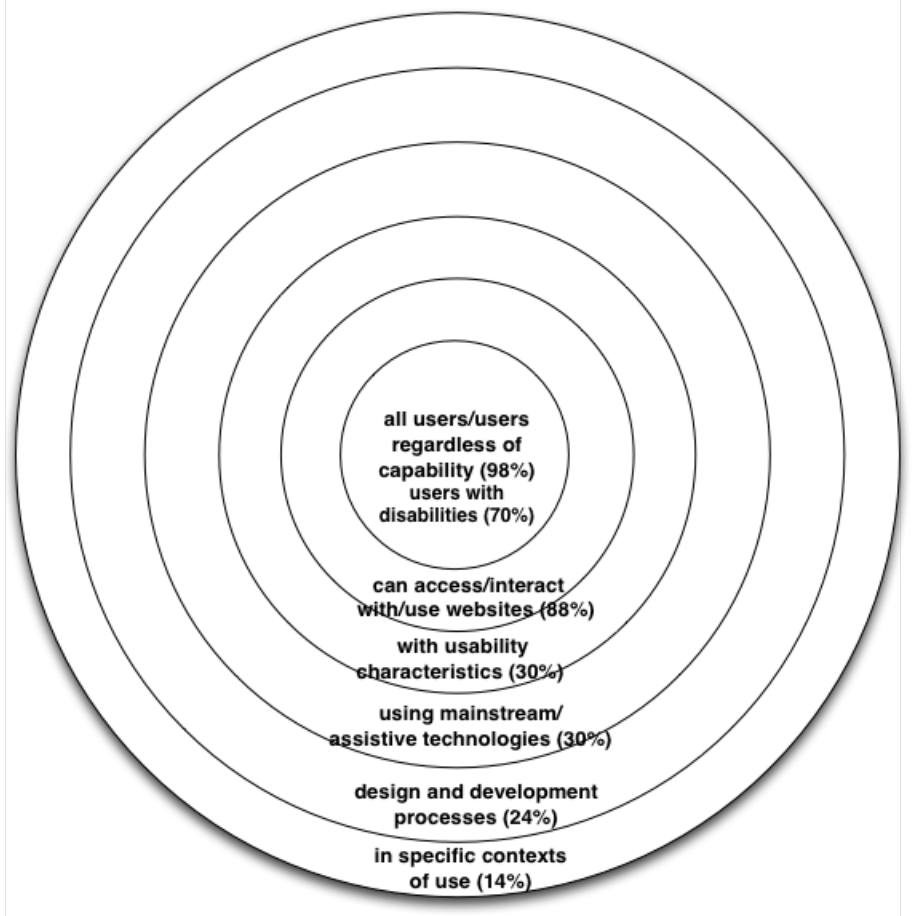

(C) Helen Petrie, Andreas Savva, Christopher Power

\section{Figure 1: Six core concepts of web accessibility emerging from the analysis of $\mathbf{5 0}$ definitions}

accessibility and constitutes an important and growing proportion of the population. The fact that this group is not often mentioned means that many researchers and practitioners may not realize it might be a relevant group, or forget to consider it in working on web accessibility.

A further result of interest is the wide number of terms used to describe what people should be able to do as a result of web accessibility. Firstly, a large number of definitions use circular definitions - defining accessibility in terms of access (20 out of 50 definitions). Strictly speaking that is not useful, but it is understandable, as authors are concentrating on explaining other parts of the concept - the users, the technologies involved etc.

It is also interesting that the WAI definition of web accessibility [9] offers an excellent set of user actions: “ ... can use ... can perceive, understand, navigate and interact with the Web". Yet few authors use these terms in full (Harper and Yesilada [14] being a notable exception), and it is disappointing that Harper and Yesilada are the only authors to mention the ability to contribute as part of web accessibility.

We also analysed the antecedents that authors quoted in relation to offering a definition of web accessibility. Surprisingly few authors refer back to previous definitions ( $24 \%$ of our sample) and very rarely discuss why they are proposing a new definition in comparison to a cited previous definition. This makes it very difficult to analyse what authors perceive to be the problems of previous definitions. However, a majority of authors $(66 \%)$ do make general citations to previous papers or standards which offer definitions. So these authors likely are aware of previous definitions, even if they do not explicitly refer to them when offering their definition.
From this analysis we can put the concepts together into a unified definition of web accessibility that almost perfectly reflects the strength of importance of the concepts, as expressed by the frequency of mention in the 50 definitions. We can illustrate this in a "layers of the onion" diagram, shown in Fig. 1, with the most important concepts at the core of the onion and concepts of less importance towards the skin of the onion.

From the onion diagram we can extract the following definition of web accessibility: "all people, particularly disabled and older people, can use websites in a range of contexts of use, including mainstream and assistive technologies; to achieve this, websites need to be designed and developed to support usability across these contexts".

This definition is long, but it includes all the components we have identified in web accessibility; this comprehensiveness we believe is pat of its strength. Figure 2 illustrates all the components of the definition and how they relate to each other.

\section{DISCUSSION AND CONCLUSIONS}

In this paper we set out to better understand what researchers and practitioners consider to be the key components of the definition of web accessibility and to propose a unified definition of web accessibility, drawing on all these components. To achieve this aim we analysed 50 definitions of web accessibility, drawn from a range of books, papers, standards, guidelines and online sources, aimed at both practitioners and researchers, from the across the time period of web accessibility work, from 1996 to 2014 and from an international selection of authors.

The analysis has led to a unified definition of web accessibility. This definition may be rather long, but accessibility is a complex concept with a large number of different components that are 


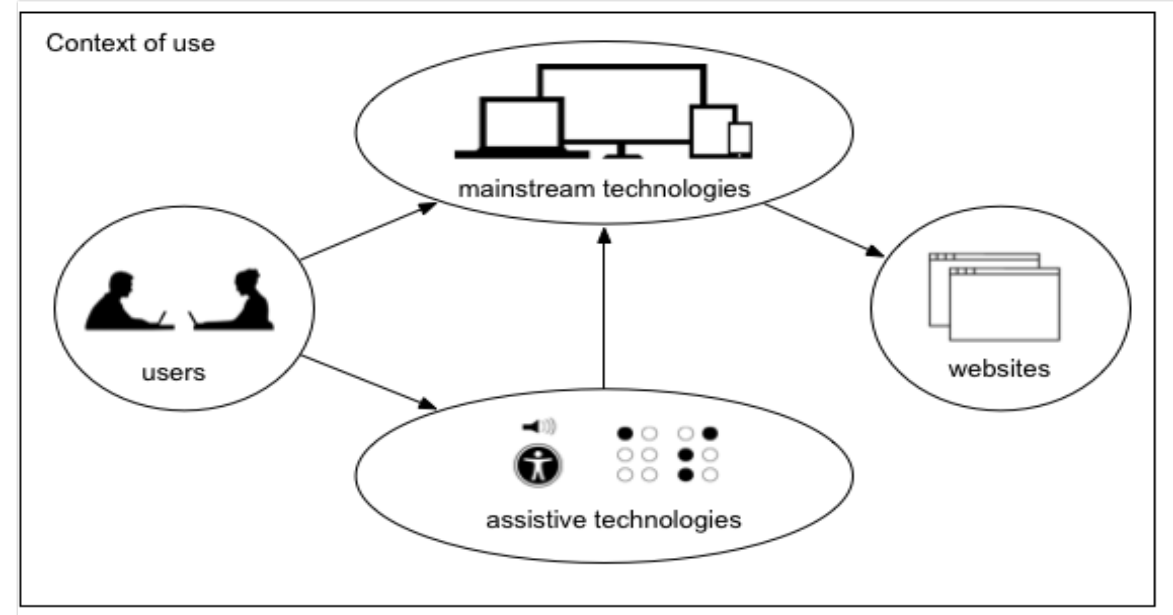

(C) Helen Petrie, Andreas Savva, Christopher Power

Figure 2: The core components of web accessibility

seldom all represented in any single definition. The "onion" diagram we have developed shows how the key concepts embedded within the unified definition fit together and makes the definition clearer for both practitioners and researchers.

There was one element of the definitions that we were surprised by that bears further investigation. Only three of the definitions included references to older adults specifically in their list of users. While these users are no doubt included in the "all users" or "anyone" related references, it is odd that they appear in so few definitions. This is odd as much of the research literature, and certainly practitioner resources, refer to older users as being within the scope of web accessibility and given that older people are an important and growing sector of the population.

This work was conducted as part of a larger literature review about web accessibility and as more papers with definitions of web accessibility are found in this review, this analysis and our unified definition of web accessibility will be refined. This paper demonstrates that, while there is often debates and conflict around the definition of web accessibility, most viewpoints and definitions about web accessibility can be reconciled into a single shared definition. We hope that this definition, which brings together many concepts from different definitions of web accessibility, will be useful to both practitioners and researchers in the field.

\section{ACKNOWLEDGEMENTS}

This work was undertaken as part of the $\mathrm{PhD}$ research for Andreas Savva. We gratefully acknowledge support for Andreas from the Cyprus State Scholarship Foundation and the Engineering and Physical Sciences Research Council of the UK.

\section{REFERENCES}

[1] Brittain, K. D. 1995. Persons with Disabilities Can and Do Surf the Net! Colorado Libraries, 21, 17-19.

[2] Paciello, M.G. 1996a. Making the World Wide Web Accessible for the Blind and Visually Impaired. Florida Libraries, 39(5).

[3] Paciello, M.G. 1996b. Making the Web Accessible for the Deaf, Hearing, and Mobility Impaired. Florida Libraries, 39, 83-91.
[4] Paciello, M.G. 1996c. The Web and People with Disabilities: Cutting Edge Developments. Florida Libraries, 39.

[5] Berners-Lee, T. 1997. W3C Leads Program to Make the Web Accessible for People with Disabilities (Press release). Available at http://www.w3.org/Press/WAI-Launch.html

[6] Thatcher, J., Bohman, P., Burks, M., Henry, S.L., Regan, B., Swierenge, S., Urban, M.D., and Waddell, C.D. 2002. Constructing Accessible Web Sites. Glasshaus, UK.

[7] Petrie, H. and Kheir, O. 2007. The Relationship between Accessibility and Usability of Websites, in Proceedings of the SIGCHI Conference on Human Factors in Computing Systems (CHI '07), ACM, New York, 397-406.

[8] Yesilada, Y., Brajnik, G.,Vigo, M., and Harper, S. 2012. Understanding Web Accessibility and its Drivers, in Proceedings of the 9th International Cross-Disciplinary Conference on Web Accessibility (W4A '12), ACM Press, New York, 19-28.

[9] W3C WAI. 2005. Introduction to Web Accessibility. Available at http://www.w3.org/WAI/intro/accessibility.php

[10] Access Board, US Government: Section 508. 1996. Available at www.section508.gov

[11] International Standards Organization (ISO). 2008. Accessibility Guidelines for Information Communication Technology (ICT) Equipment and Services (ISO 9241-20), ISO, Geneva.

[12] British Standards Institute (BSI). 2010. Web Accessibility Code of Practice (BS 8788:2010), BSI, London.

[13] Maswera, T., Dawson, R. and Edwards, J. 2005. Analysis of usability and accessibility errors of e-commerce websites of tourist organisations in four African countries. In Proceedings of the Conference on Information and Communications Technologies in Tourism (Innsbruck, Austria, January 26 - 28 2005), Springer Wien, pp. 531-542.

[14] Harper, S. and Yesilada, Y. 2008. Web accessibility. In Harper, S., Yesilada, Y. (eds), Web accessibility: $A$ foundation for research. Springer Berlin Heidelberg. 
Appendix. 50 definitions of web accessibility.

\begin{tabular}{|c|c|c|c|c|c|}
\hline Source & Reference & Country & Definition & $\begin{array}{c}\text { Antecedents to } \\
\text { definition }\end{array}$ & $\begin{array}{c}\text { General } \\
\text { Antecedents }\end{array}$ \\
\hline \multicolumn{6}{|l|}{ Standards and guidelines } \\
\hline Section 508 (1996) & $\begin{array}{l}\text { Access Board, US Government: Section 508. } 1996 . \\
\text { Available at www.section508.gov }\end{array}$ & USA & $\begin{array}{l}\text { Technology is accessible if it can be used as } \\
\text { effectively by people with disabilities as by those } \\
\text { without. }\end{array}$ & & \\
\hline WAI/W3C (2005) & $\begin{array}{l}\text { W3C WAI. 2005. Introduction to Web } \\
\text { Accessibility. Available } \\
\text { at http://www.w3.org/WAI/intro/accessibility.php }\end{array}$ & International & $\begin{array}{l}\text {... people with disabilities can use the Web. More } \\
\text { specifically, Web accessibility means that people } \\
\text { with disabilities can perceive, understand, navigate, } \\
\text { and interact with the Web, and that they can } \\
\text { contribute to the Web. }\end{array}$ & & \\
\hline ISO 9241-171 (2008) & $\begin{array}{l}\text { International Standards Organization (ISO). } 2008 . \\
\text { Accessibility Guidelines for Information } \\
\text { Communication Technology (ICT) Equipment and } \\
\text { Services (ISO 9241-20), ISO, Geneva. }\end{array}$ & International & $\begin{array}{l}\ldots \text { the usability of a product, service, environment or } \\
\text { facility by people with the widest range of } \\
\text { capabilities. }\end{array}$ & & \\
\hline BSI (2010) & $\begin{array}{l}\text { British Standards Institute (BSI). 2010. Web } \\
\text { Accessibility Code of Practice (BS 8788:2010), } \\
\text { BSI, London. }\end{array}$ & UK & $\begin{array}{l}\text { The extent to which a website can be used by users } \\
\text { with specified disabilities to achieve specified goals } \\
\text { with effectiveness, efficiency and satisfaction in a } \\
\text { specified context of use. }\end{array}$ & & \\
\hline \multicolumn{6}{|c|}{ Books, papers, online documents } \\
\hline Paciello (1996) & $\begin{array}{l}\text { Paciello, M.G. 1996. Making the web accessible for } \\
\text { the deaf, hearing, and mobility impaired. Florida } \\
\text { Libraries, 39, 83-91. }\end{array}$ & USA & $\begin{array}{l}\text {... the ability for [web] browsers to render } \\
\text { information in a manner that is accessible to people } \\
\text { with disabilities. For the blind, any aspect of a } \\
\text { graphic interface presents barriers. For low vision } \\
\text { web surfers (and in some cases, those with cognitive } \\
\text { limitations), data presentation in different formats, } \\
\text { different fonts, and inconsistent character and word } \\
\text { spacing, make reading online information difficult. } \\
\text { For the deaf, rendering sounds or sound bytes } \\
\text { presents significant challenges. }\end{array}$ & & \\
\hline Berners-Lee (1997) & $\begin{array}{l}\text { Berners-Lee, T. 1997. W3C Leads program to } \\
\text { make the web accessible for people with disabilities } \\
\text { (Press release on launch of WAI). Available } \\
\text { at http://www.w3.org/Press/WAI-Launch.html }\end{array}$ & USA & $\begin{array}{l}\ldots \text { it is critical that the Web be usable by anyone, } \\
\text { regardless of individual capabilities and disabilities. }\end{array}$ & & \\
\hline Letourneau (1998- 2009) & $\begin{array}{l}\text { Letourneau, C.: 1998-2009. Accessible web design } \\
\text { - A definition. Available at } \\
\text { www.starlingweb.com/webac.htm }\end{array}$ & Canada & $\begin{array}{l}\text {... anyone using any kind of web browsing } \\
\text { technology must be able to visit any site and get a full } \\
\text { and complete understanding of the information as } \\
\text { well as have the full and complete ability to interact }\end{array}$ & & \\
\hline
\end{tabular}




\begin{tabular}{|c|c|c|c|c|c|}
\hline & & & with the site if that is necessary. & & \\
\hline Waddell (1998) & $\begin{array}{l}\text { Waddell. C.D. 1998. Applying the ADA to the } \\
\text { internet: A web accessibility standard. Paper } \\
\text { presented at the American Bar Association National } \\
\text { Conference. Available at } \\
\text { http://lists.w3.org/Archives/Public/w3c-wai- } \\
\text { ig/1998AprJun/0336.html }\end{array}$ & USA & $\begin{array}{l}\text {...the design of a webpage } \ldots \text { in order to ensure that } \\
\text { all users can access the information on the page. }\end{array}$ & & \\
\hline Sierkowski (2002) & $\begin{array}{l}\text { Sierkowski, B. 2002. Achieving web accessibility. } \\
\text { In Proceedings of the } 30 \text { th Annual ACM SIGUCCS } \\
\text { Conference on User Services (Providence, RI } \\
\text { November } 20-23,2002 \text { ). ACM, New York, NY, } \\
288-291 \text {. } \\
\text { DOI=http://dx.doi.org/10.1145/588646.588725 }\end{array}$ & USA & $\begin{array}{l}\text { Web accessibility is the ability for a person using any } \\
\text { user agent (software or hardware that retrieves and } \\
\text { renders web content) to understand and fully interact } \\
\text { with a website's content. The idea of accessibility is } \\
\text { based on more than the implementation of standards; } \\
\text { it embodies the idea that everyone has the right to be } \\
\text { included in society, regardless of disability, } \\
\text { geographical location, language barriers, or any other } \\
\text { factor. ( } \mathrm{p} 288 \text { ) }\end{array}$ & $\begin{array}{l}\text { Thatcher et al } \\
\text { (2002) }\end{array}$ & $\begin{array}{l}\text { Section } 508 \\
\text { WCAG }\end{array}$ \\
\hline Slatin and Rush (2002) & $\begin{array}{l}\text { Slatin, J.M. and Rush, S. 2002. Maximum } \\
\text { accessibility: Making your website more usable for } \\
\text { everyone. Addison- Wesley Longman Publishing, } \\
\text { Boston. }\end{array}$ & USA & $\begin{array}{l}\ldots \text { individuals with disabilities can access and use } \\
\text { them [websites] as effectively as people who don't } \\
\text { have disabilities. (p 3) }\end{array}$ & & \\
\hline Thatcher et al (2002) & $\begin{array}{l}\text { Thatcher, J., Bohman, P., Burks, M., Henry, S.L., } \\
\text { Regan, B., Swierenge, S., Urban, M.D., and } \\
\text { Waddell, C.D. 2002. Constructing Accessible Web } \\
\text { Sites. Glasshaus, Birmingham, UK. }\end{array}$ & USA & $\begin{array}{l}\text {... people being able to get and use web content. It is } \\
\text { about designing web pages that people can present } \\
\text { and interact with according to their needs and } \\
\text { preferences. A primary focus of accessibility is } \\
\text { access by people with disabilities. The larger scope of } \\
\text { accessibility includes benefits to people without } \\
\text { disabilities ... Accessibility is a subset of a more } \\
\text { general pursuit: usability. (p 7) }\end{array}$ & & $\begin{array}{l}\text { Section } 508 \\
\text { WCAG }\end{array}$ \\
\hline $\begin{array}{l}\text { Abascal, Arrue, Garay and } \\
\text { Tomás (2003) }\end{array}$ & $\begin{array}{l}\text { Abascal, J. Arrue, M. Garay, N., and Tomás, J. } \\
\text { 2003. A web service for automatic accessibility } \\
\text { analysis of web pages based on the use of XML } \\
\text { structures. In Proceedings of the 10th International } \\
\text { Conference on Human-Computer Interaction } \\
\text { (Crete, Greece, June } 22-27,2003 \text { ). Lawrence } \\
\text { Erlbaum Associates, Hillsdale, NJ, 925-929. }\end{array}$ & Spain & $\begin{array}{l}\text { Web Accessibility refers to the possibility of } \\
\text { accessing any web content by anyone regardless to } \\
\text { circumstances such as impairments, platforms, } \\
\text { devices, browsers, etc. (p 925) }\end{array}$ & & WCAG \\
\hline Lazar et al (2003) & $\begin{array}{l}\text { Lazar, J., Schroeder-Thomas, C., Jones, A., } \\
\text { Greenidge, K., Beere, P., and Clements, J. } 2003 . \\
\text { Detour ahead: Current roadblocks to web } \\
\text { accessibility. In Proceedings of the } 2 \text { nd }\end{array}$ & USA & $\begin{array}{l}\text { An accessible web site is a web site that can be } \\
\text { successfully used by people with various disabilities. } \\
\text { People with different disabilities may be using } \\
\text { different forms of assistive technology, such as }\end{array}$ & & $\begin{array}{l}\text { Section } 508 \\
\text { WCAG } \\
\text { Slatin and Rush } \\
(2002)\end{array}$ \\
\hline
\end{tabular}




\begin{tabular}{|c|c|c|c|c|c|}
\hline & $\begin{array}{l}\text { International Conference on Universal Access in } \\
\text { Human-Computer Interaction (UAHCI) (Crete, } \\
\text { Greece, June } 22-27,2003 \text { ). Lawrence Erlbaum } \\
\text { Associates, Hillsdale, NJ, 990-994. }\end{array}$ & & $\begin{array}{l}\text { screen readers, alternative keyboards, or alternative } \\
\text { pointing devices. A web site that is accessible is } \\
\text { flexible enough to work with these various assistive } \\
\text { technology devices. (p 990) }\end{array}$ & & \\
\hline $\begin{array}{l}\text { Thompson, Burgstahler and } \\
\text { Comden (2003) }\end{array}$ & $\begin{array}{l}\text { Thompson, T., Burgstahler, S., and Comden, D. } \\
\text { 2003. Research on web accessibility in higher } \\
\text { education. Journal of Information Technology and } \\
\text { Disabilities, 9(2) (December 2003). }\end{array}$ & USA & $\begin{array}{l}\text { The bottom line with respect to web accessibility is } \\
\text { whether an individual can perform a website's } \\
\text { intended function(s). As there will be varying degrees } \\
\text { in the ease with which users can do so, such a } \\
\text { measure does not lend itself to a binary "approved" } \\
\text { or "not approved" rating. With this in mind, the } \\
\text { evaluator of any web page should (a) identify its } \\
\text { perceived intended function(s) and (b) rate the page } \\
\text { on a scale that measures the ease with which any } \\
\text { user, including a user with a disability, can perform } \\
\text { the intended function(s). }\end{array}$ & & $\begin{array}{l}\text { Section } 508 \\
\text { WCAG }\end{array}$ \\
\hline $\begin{array}{l}\text { Hackett, Parmanto and Zeng } \\
\text { (2004) }\end{array}$ & $\begin{array}{l}\text { Hackett, S., Parmanto, B., and Zeng, X. } 2004 . \\
\text { Accessibility of Internet websites through time. In } \\
\text { Proceedings of the } 6^{\text {th }} \text { International ACM } \\
\text { SIGACCESS Conference on Computers and } \\
\text { Accessibility (ASSETS '04) (Atlanta, GA, USA, } \\
\text { October } 18-20,2004) \text {. ACM, New York, 32-39. } \\
\text { DOI=http://dx.doi.org/10.1145/1029014.1028638 }\end{array}$ & USA & $\begin{array}{l}\text { Accessibility, when pertaining to a Web page, means } \\
\text { that information has been made available for use by } \\
\text { almost everyone, including persons. with disabilities. } \\
\text { This accessibility may be } \\
\text { direct or through the use of assistive technologies. }\end{array}$ & & $\begin{array}{l}\text { Section } 508 \\
\text { WCAG }\end{array}$ \\
\hline $\begin{array}{l}\text { Abanumy, Al-Badi and } \\
\text { Mayhew (2005) }\end{array}$ & $\begin{array}{l}\text { Abanumy, A., Al-Badi, A., and Mayhew, P. } 2005 . \\
\text { e- Government website accessibility: In-depth } \\
\text { evaluation of Saudi Arabia and Oman. The } \\
\text { Electronic Journal of e- Government, 3(3) } \\
\text { (December 2005) 99-106. }\end{array}$ & UK & $\begin{array}{l}\text { Web accessibility refers to the degree to which web } \\
\text { information is accessible to all human beings and } \\
\text { automatic tools. The goal of web accessibility is to } \\
\text { allow universal access to information on the web, by } \\
\text { all people but especially by people with any } \\
\text { impairment, no matter what its severity, (e.g. } \\
\text { blindness, low vision, deafness, hard of hearing, } \\
\text { physical disabilities or cognitive disabilities). In } \\
\text { addition, the information must be accessible by } \\
\text { automatic machine tools. (p100) }\end{array}$ & $\begin{array}{l}\text { Letourneau } \\
(1998-2009)\end{array}$ & $\begin{array}{l}\text { Section } 508 \\
\text { WCAG }\end{array}$ \\
\hline $\begin{array}{l}\text { Mankoff, Fait and Tran } \\
\text { (2005) }\end{array}$ & $\begin{array}{l}\text { Mankoff J., Fait, H., and Tran, T. 2005. Is your web } \\
\text { page accessible?: A comparative study of methods } \\
\text { for assessing web page accessibility for the blind. } \\
\text { In Proceedings of the SIGCHI Conference on } \\
\text { Human Factors in Computing Systems (Portland, } \\
\text { Oregon, USA, April } 2-7,2005 \text { ) (CHI '05), ACM, } \\
\text { New York, 41-50. DOI= http://dx.doi.org/ }\end{array}$ & USA & $\begin{array}{l}\text { Web accessibility involves making web content } \\
\text { available to all individuals, regardless of any } \\
\text { disabilities or environmental constraints they } \\
\text { experience. (p 41) }\end{array}$ & & $\begin{array}{l}\text { Section } 508 \\
\text { WCAG } \\
\text { Paciello (2000) } \\
\text { Thatcher et al } \\
\text { (2002) }\end{array}$ \\
\hline
\end{tabular}




\begin{tabular}{|c|c|c|c|c|c|}
\hline & $10.1145 / 1054972.1054979$ & & & & \\
\hline $\begin{array}{l}\text { Maswera, Dawson, and } \\
\text { Edwards (2005) }\end{array}$ & $\begin{array}{l}\text { Maswera, T., Dawson, R. and Edwards, J. } 2005 . \\
\text { Analysis of usability and accessibility errors of e- } \\
\text { commerce websites of tourist organisations in four } \\
\text { African countries. In Proceedings of the } \\
\text { Conference on Information and Communications } \\
\text { Technologies in Tourism (Innsbruck, Austria } \\
\text { January } 26 \text { - } 28 \text { 2005), Springer Wien, pp. 531- } \\
542 \text {. }\end{array}$ & UK & $\begin{array}{l}\text {... the most important component in web } \\
\text { accessibility is addressing issues relevant to } \\
\text { individuals with disabilities and the elderly } \\
\text { (p532) }\end{array}$ & $\begin{array}{l}\text { Letourneau } \\
\text { (1998) }\end{array}$ & $\begin{array}{l}\text { WCAG } \\
\text { Sierkowski } \\
(2002)\end{array}$ \\
\hline Brajnik (2006) & $\begin{array}{l}\text { Brajnik, G. 2006. Web accessibility testing: When } \\
\text { the method is the culprit. In Miesenberger, K., } \\
\text { Klaus, J., Zagler, W., Karshmer, A. (eds.) } \\
\text { Proceedings of the } 10^{\text {th }} \text { International Conference } \\
\text { on Computers Helping People with Special Needs } \\
\text { (ICCHP) 2006. LNCS, vol. 4061, Springer Berlin } \\
\text { Heidelberg, 156-163. }\end{array}$ & Italy & $\begin{array}{l}\text { Sometimes accessibility is defined in terms of } \\
\text { effective- ness; now and then it is defined in terms of } \\
\text { usability; but unfortunately there are too often claims } \\
\text { that a web site is accessible simply because an } \\
\text { automatic accessibility testing tool yielded no error. }\end{array}$ & & $\begin{array}{l}\text { Section } 508 \\
\text { WCAG } \\
\text { Slatin and Rush } \\
(2002)\end{array}$ \\
\hline Chen, Chen and Shao (2006) & $\begin{array}{l}\text { Chen, Y.-L., Chen, Y.-Y., and Shao, M. 2006. } 2005 \\
\text { accessibility diagnosis on the government web sites } \\
\text { in Taiwan, R.O.C. In Proceedings of the } 2006 \\
\text { International Cross-disciplinary Workshop on Web } \\
\text { Accessibility (W4A): Building the Mobile Web: } \\
\text { rediscovering accessibility? (Edinburgh, Scotland, } \\
\text { UK, May } 22 \text { - 23, 2006) (W4A '06). ACM, New } \\
\text { York, 132-142. DOI = } \\
\text { http://dx.doi.org/10.1145/1133219.1133243 }\end{array}$ & Taiwan & $\begin{array}{l}\text { In general, accessible websites are able to give } \\
\text { everyone equal opportunities to access the complete } \\
\text { Web content regardless of software, hardware and } \\
\text { user ability. }\end{array}$ & $\begin{array}{l}\text { Sierkowski } \\
(2002)\end{array}$ & $\begin{array}{l}\text { Section } 508 \\
\text { WCAG }\end{array}$ \\
\hline $\begin{array}{l}\text { Iaccarino, Malandrino and } \\
\text { Scarano }(2006)\end{array}$ & $\begin{array}{l}\text { Iaccarino, G., Malandrino, D., and Scarano, V. } \\
\text { 2006. Personalizable edge services for web } \\
\text { accessibility. In Proceedings of the } 2006 \\
\text { international cross-disciplinary workshop on Web } \\
\text { accessibility (W4A) (Edinburgh, Scotland, UK, } \\
\text { May } 22 \text { - 23, 2006) (W4A '06). ACM, New York, } \\
\text { 23-32. } \\
\text { DOI=http://dx.doi.org/10.1145/1133219.1133224 }\end{array}$ & Italy & $\begin{array}{l}\text { More specifically, Web accessibility means that } \\
\text { people with disabilities can easily navigate and } \\
\text { interact with the Web. }\end{array}$ & & WCAG \\
\hline Jaeger (2006) & $\begin{array}{l}\text { Jaeger, P. T. 2006. Assessing Section } 508 \\
\text { compliance on federal e-government web sites: A } \\
\text { multi-method, user- centered evaluation of } \\
\text { accessibility for persons with disabilities. }\end{array}$ & USA & $\begin{array}{l}\text { For a web site to be accessible, it should provide } \\
\text { equal or equivalent access to all users, and it should } \\
\text { work compatibly with assistive technologies such as } \\
\text { narrators, screen enlargement, and many other }\end{array}$ & & $\begin{array}{l}\text { Section } 508 \\
\text { WCAG } \\
\text { Thompson, } \\
\text { Burgstahler and }\end{array}$ \\
\hline
\end{tabular}




\begin{tabular}{|c|c|c|c|c|}
\hline & $\begin{array}{l}\text { Government Information Quarterly, 23(2) (June } \\
\text { 2006), 169-190. } \\
\text { DOI=http://dx.doi.org/10.1016/j.giq.2006.03.002 }\end{array}$ & & $\begin{array}{l}\text { devices that persons with disabilities may employ to } \\
\text { navigate cyberspace. }(\mathrm{p} 170)\end{array}$ & $\begin{array}{l}\text { Comden (2003) } \\
\text { Slatin and Rush } \\
\text { (2002) }\end{array}$ \\
\hline Craven and Nietzio (2007) & $\begin{array}{l}\text { Craven, J. and Nietzio, A. 2007. A task-based } \\
\text { approach to assessing the accessibility of web sites. } \\
\text { Performance Measurement and Metrics, 8(2) } \\
\text { (2007), 98-109. DOI= } \\
\text { http://dx.doi.org/10.1108/14678040710760603 }\end{array}$ & $\begin{array}{c}\text { UK } \\
\text { Germany }\end{array}$ & $\begin{array}{l}\text { The term web accessibility can refer to the provision } \\
\text { of physical access to appropriate hardware and } \\
\text { software to enable access to the web; it can mean the } \\
\text { provision of add-on technologies to widen access to } \\
\text { the web, for example through the use of assistive } \\
\text { technologies such as screen reading software, screen } \\
\text { magnification, alterative mouse devices, and voice } \\
\text { input. Web accessibility can also refer to the design } \\
\text { of the web interface which, according to } \\
\text { recommended standards and guidelines, should be } \\
\text { presented in a way that can be interpreted by as wide } \\
\text { a group of user as possible and by any kind of } \\
\text { assistive technology. (p } 98-99)\end{array}$ & WCAG \\
\hline Henry (2007) & $\begin{array}{l}\text { Henry, S. 2007. Just ask. Integrating accessibility } \\
\text { throughout design. Lulu Books, Raleigh NC. }\end{array}$ & USA & $\begin{array}{l}\text {... means that people with disabilities can use a } \\
\text { product (p 2) }\end{array}$ & $\begin{array}{l}\text { Section } 508 \\
\text { WCAG }\end{array}$ \\
\hline Kane (2007) & $\begin{array}{l}\text { Kane, S. 2007. Everyday inclusive web design: an } \\
\text { activity perspective. Information Research, 12(3) } \\
\text { (April 2007). Available at } \\
\text { http://www.informationr.net/ir/12-3/paper309.html }\end{array}$ & USA & $\begin{array}{l}\text { Web accessibility refers to the degree to which a } \\
\text { website may be accessed by people with varying } \\
\text { abilities. }\end{array}$ & $\begin{array}{l}\text { WCAG } \\
\text { Section } 508 \\
\text { Paciello (2000) }\end{array}$ \\
\hline Petrie and Kheir (2007) & $\begin{array}{l}\text { Petrie, H. and Kheir, O. 2007. The relationship } \\
\text { between accessibility and usability of websites. In } \\
\text { Proceedings of the SIGCHI Conference on Human } \\
\text { Factors in Computing Systems, (San Jose, } \\
\text { California, USA) (CHI '07), ACM, New York, } \\
\text { 397-406. DOI= } \\
\text { http://dx.doi.org/10.1145/1240624.1240688 }\end{array}$ & UK & $\begin{array}{l}\text {... the ultimate criteria for accessibility should be } \\
\text { user- based and we can adapt the ISO } 9241 \text { definition } \\
\text { for this purpose: the extent to which a } \\
\text { product/website can be used by specified users with } \\
\text { specified disabilities to achieve specified goals with } \\
\text { effectiveness, efficiency and satisfaction in a } \\
\text { specified context of use. (p 397) }\end{array}$ & $\begin{array}{l}\text { WCAG } \\
\text { Brajnik (2006) } \\
\text { Thatcher et al } \\
(2002)\end{array}$ \\
\hline $\begin{array}{l}\text { Watanabe, Asai and Asano } \\
\text { (2007) }\end{array}$ & $\begin{array}{l}\text { Watanabe, M., Asai, D., and Asano, Y. } 2007 . \\
\text { Improving accessibility through the visual structure } \\
\text { of web contents. In Proceedings of the } 4^{\text {th }} \\
\text { International Conference on Universal Access in } \\
\text { Human-Computer Interaction, UAHCI } 2007 \text { Held } \\
\text { as Part of HCI International. (Beijing, China, July } \\
22-27,2007) .185-192 . \text { DOI=10.1007/978-3-540- } \\
73283-922\end{array}$ & Japan & $\begin{array}{l}\text { Web accessibility means the ability [of websites] to } \\
\text { be accessed by all kinds of people or devices. }\end{array}$ & WCAG \\
\hline Chisholm and May (2008) & $\begin{array}{l}\text { Chisholm, W. and May, M. 2008. Universal design } \\
\text { for web applications. O'Reilly Media, Sebastapol, }\end{array}$ & USA & $\begin{array}{l}\ldots \text { to increase usability for people with disabilities } \\
\text { and in scenarios involving mobile and embedded }\end{array}$ & WCAG \\
\hline
\end{tabular}




\begin{tabular}{|c|c|c|c|c|c|}
\hline & CA. & & devices. (p xi) & & \\
\hline Harper and Yesilada (2008) & $\begin{array}{l}\text { Harper, S. and Yesilada, Y. 2008. Web } \\
\text { accessibility. In Harper, S., Yesilada, Y. (eds), Web } \\
\text { accessibility: A foundation for research. Springer } \\
\text { Berlin Heidelberg. }\end{array}$ & $\begin{array}{c}\text { UK } \\
\text { Cyprus }\end{array}$ & $\begin{array}{l}\text { Web accessibility aims to help these people [who } \\
\text { have disabilities] to perceive, understand, navigate, } \\
\text { and interact with, as well as contribute to, the Web, } \\
\text { and thereby the society in general. This accessibility } \\
\text { is, in part, facilitated by the Web Content } \\
\text { Accessibility Guidelines (WCAG) currently moving } \\
\text { from version one to two. (p 61) }\end{array}$ & WCAG & Section 508 \\
\hline $\begin{array}{l}\text { Freire, Fortes, Turine, and } \\
\text { Paiva (2008) }\end{array}$ & $\begin{array}{l}\text { Freire, A.P.,-Fortes, R.P.M., Turine, M.A.S. and } \\
\text { Paiva, D.M.B. 2008. An evaluation of web } \\
\text { accessibility metrics based on their attributes. In } \\
\text { Proceedings of the } 26 \text { th annual ACM International } \\
\text { Conference on Design of Communication (Lisbon, } \\
\text { Portugal, September } 22-24,2008 \text { ) SIGDOC '08. } \\
\text { ACM, New York, NY, 73-79. DOI= }\end{array}$ & Brazil & $\begin{array}{l}\text { Accessibility is a concept related to providing access } \\
\text { to Web content to people with different abilities and } \\
\text { people using different devices. (p73) }\end{array}$ & & $\begin{array}{l}\text { Berners-Lee } \\
\text { (1997) }\end{array}$ \\
\hline Leporini and Paternò (2008) & $\begin{array}{l}\text { Leporini, B. and Paternò, F. 2008. Applying web } \\
\text { usability criteria for vision-impaired users: Does it } \\
\text { really improve task performance? International } \\
\text { Journal of Human-Computer Interaction, 24(1) } \\
\text { (January 2008), 17-47. DOI= } \\
10.1080 / 10447310701771472\end{array}$ & Italy & $\begin{array}{l}\text {... it is important that the information be easily } \\
\text { reachable by all, including people with disabilities. (p } \\
\text { 17) Accessibility is aimed specifically at making } \\
\text { Web sites more available to a wider population of } \\
\text { users (including special categories) by removing the } \\
\text { technical barriers that prevent access to the } \\
\text { information included in the site (p 17) }\end{array}$ & & $\begin{array}{l}\text { Abascal, Arrue, } \\
\text { Fajardo, Garay } \\
\text { and Tomas } \\
\text { (2003) } \\
\text { Section } 508 \\
\text { WCAG } \\
\text { Mankoff, Fait, } \\
\text { and Tran (2005) }\end{array}$ \\
\hline $\begin{array}{l}\text { Borrino, Furini and Roccetti } \\
\text { (2009) }\end{array}$ & $\begin{array}{l}\text { Borrino, R., Furini, M., and Roccetti, M. } 2009 . \\
\text { Augmenting social media accessibility. In } \\
\text { Proceedings of the } 2009 \text { International Cross- } \\
\text { Disciplinary Conference on Web Accessibililty } \\
\text { (W4A) (Madrid, Spain, April } 20 \text { - 21, 2009) (W4A } \\
\text { '09). ACM, New York, 54-57. }\end{array}$ & Italy & $\begin{array}{l}\text { Web accessibility means that people with disabilities, } \\
\text { including older people with changing abilities, can } \\
\text { perceive, understand, navigate, and interact with the } \\
\text { Web. (p55) }\end{array}$ & & \\
\hline Alexandru and Alecu (2010) & $\begin{array}{l}\text { Alexandru, A. and Alecu, C. S. 2010. Introducing } \\
\text { engineering students to telemedicine. Case study. In } \\
\text { Proceedings of the 7th WSEAS International } \\
\text { Conference on Engineering Education. World } \\
\text { Scientific and Engineering Academy and Society } \\
\text { (WSEAS). (Corfu, Greece, July } 22-24,2010) 465- \\
469 .\end{array}$ & Romania & $\begin{array}{l}\text { Web accessibility refers to making the World Wide } \\
\text { Web accessible and available to everyone, including } \\
\text { people with disabilities and senior citizens. }\end{array}$ & & WCAG \\
\hline $\begin{array}{l}\text { Bradbard, Peters, and Caneva } \\
\text { (2010) }\end{array}$ & $\begin{array}{l}\text { Bradbard, D. A., Peters, C., and Caneva, Y. } 2010 . \\
\text { Web accessibility policies at land-grant } \\
\text { universities. The Internet and Higher Education. }\end{array}$ & USA & $\begin{array}{l}\text { Web accessibility is the practice of making Web sites } \\
\text { accessible to people who require more than just } \\
\text { traditional Web browsers to access the Internet. }\end{array}$ & & $\begin{array}{l}\text { Section } 508, \\
\text { WCAG, } \\
\text { Hackett, }\end{array}$ \\
\hline
\end{tabular}




\begin{tabular}{|c|c|c|c|c|c|}
\hline & $\begin{array}{l}\text { 13(4) (May 2010), 258-266. DOI=http://dx.doi.org/ } \\
\text { 10.1016/j.iheduc.2010.05.007 }\end{array}$ & & & & $\begin{array}{l}\text { Parmanto and } \\
\text { Zeng (2005) }\end{array}$ \\
\hline Isaila and Nicolau (2010) & $\begin{array}{l}\text { Isaila, N. and Nicolau, I. 2010. Promoting computer } \\
\text { assisted learning for persons with disabilities. } \\
\text { Procedia-Social and Behavioral Sciences, 2(2), } \\
\text { (May 2010), } 4497 \text { - 4501. DOI= } \\
\text { http://dx.doi.org/10.1016/j.sbspro.2010.03.719 }\end{array}$ & Romania & $\begin{array}{l}\text { Web accessibility refers to persons with disabilities } \\
\text { which access the Web content. From this point of } \\
\text { view, Web accessibility means a web design that } \\
\text { allows people with disabilities to interact with Web } \\
\text { pages effectively. }\end{array}$ & WCAG & \\
\hline Lopes and Carrico (2010) & $\begin{array}{l}\text { Lopes, R. and Carrico, L. 2010. Macroscopic } \\
\text { characterisations of web accessibility. New Review } \\
\text { of Hypermedia and Multimedia, 16(3) (December } \\
\text { 2010), 221-243. DOI= } \\
\text { http://dx.doi.org/10.1080/13614568.2010.534185 }\end{array}$ & Portugal & $\begin{array}{l}\text { Web accessibility is an umbrella term for the study of } \\
\text { the adequacy of Web technologies to users with } \\
\text { special needs such as people with blindness, } \\
\text { cognitive disabilities, etc. This adequacy can be } \\
\text { viewed from two perspectives: (1) stricter, where } \\
\text { accessibility means the ability to access (e.g. a person } \\
\text { with blindness cannot grasp information conveyed in } \\
\text { images); and (2) broader, where the term represents } \\
\text { how easily these users can interact with a Web page. }\end{array}$ & WCAG & \\
\hline $\begin{array}{l}\text { Martín, Mazalu and Cechich } \\
\text { (2010) }\end{array}$ & $\begin{array}{l}\text { Martín, A., Mazalu, R., and Cechich, A. } 2010 . \\
\text { Supporting an aspect-oriented approach to web } \\
\text { accessibility design. In Proceedings of the Fifth } \\
\text { International Conference on Software Engineering } \\
\text { Advances (ICSEA), (Nice, France, August } 22-27 \text { ) } \\
\text { (2010), IEEE, 20-25. DOI= } \\
\text { http://dx.doi.org/10.1109/ICSEA.2010.10 }\end{array}$ & Argentina & $\begin{array}{l}\text { Web Accessibility means universal access on the } \\
\text { Web, regardless the kind of hardware, software, } \\
\text { network platform, language, culture, geographic } \\
\text { location and users' capabilities. }\end{array}$ & WCAG & \\
\hline $\begin{array}{l}\text { Wijayaratne and Singh } \\
(2010)\end{array}$ & $\begin{array}{l}\text { Wijayaratne, A. and Singh, D. 2010. Is there space } \\
\text { in cyberspace for distance learners with special } \\
\text { needs in Asia? A review of the level of web } \\
\text { accessibility of institutional and library homepages } \\
\text { of AAOU members. The International Information } \\
\text { and Library Review, } 42(1) \text { (February 2010), } 40-49 \text {. } \\
\text { DOI= http://dx.doi.org/10.1016/j.iilr.2010.01.002 }\end{array}$ & $\begin{array}{l}\text { Sri Lanka } \\
\text { Malaysia }\end{array}$ & $\begin{array}{l}\text { Accessibility is making the content of a Website } \\
\text { available to everyone, including those with physical } \\
\text { disabilities and cognitive learning problems. }\end{array}$ & & $\begin{array}{l}\text { Section } 508 \\
\text { WCAG } \\
\text { Thompson, } \\
\text { Burgstahler and } \\
\text { Comden (2003) }\end{array}$ \\
\hline $\begin{array}{l}\text { Belingardi and Obradovic } \\
\text { (2011) }\end{array}$ & $\begin{array}{l}\text { Belingardi, G. and Obradovic, J. 2011. Experience } \\
\text { of use of advanced communication systems and } \\
\text { distance learning to support teaching at Politecnico } \\
\text { di Torino. International Journal of Industrial } \\
\text { Engineering and Management (IJIEM), 2(4) } \\
\text { (2011), 159-163. }\end{array}$ & Italy & $\begin{array}{l}\text { Web accessibility refers to the ability to use content } \\
\text { and services independently of the disability and } \\
\text { hardware and software availability. }\end{array}$ & WCAG & \\
\hline Lazar et al (2011) & $\begin{array}{l}\text { Lazar, J., Wentz, B., Bogdan, M., Clowney, E., } \\
\text { Davis, M., Guiffo, J., Gunnarsson, D., Hanks, D., } \\
\text { Harris, J., Holt, B., Kitchin, M., Motayne, M., }\end{array}$ & USA & $\begin{array}{l}\text { Web accessibility is the concept of making sure that } \\
\text { web sites can work properly for users with disabilities } \\
\text { that are using alternative input or output devices, }\end{array}$ & $\begin{array}{l}\text { Section } 508 \\
\text { WCAG }\end{array}$ & $\begin{array}{l}\text { Jaeger (2006) } \\
\text { Mankoff, Fait } \\
\text { and Tran (2005) }\end{array}$ \\
\hline
\end{tabular}




\begin{tabular}{|c|c|c|c|c|c|}
\hline & $\begin{array}{l}\text { Nzokou, R., Sedaghat, L., and Stern, K. } 2011 . \\
\text { Potential pricing discrimination due to inaccessible } \\
\text { web sites. In Proceedings of the } 13^{\text {th }} \text { IFIP TC } 13 \\
\text { International Conference on Human-Computer } \\
\text { Interaction. (Lisbon, Portugal, September } 5-9 \\
\text { 2011). Springer Berlin Heidelberg, 108-114. }\end{array}$ & & such as screen readers or adaptive keyboards. & & \\
\hline Baowaly and Bhuiyan (2012) & $\begin{array}{l}\text { Baowaly, M. K. and Bhuiyan, M. } 2012 . \\
\text { Accessibility analysis and evaluation of Bangladesh } \\
\text { government website. In Proceedings of the } 2012 \\
\text { International Conference on } \\
\text { Informatics, Electronics \& Vision (ICIEV), (Dhaka, } \\
\text { Bangladesh, May } 18-19,2012), 46-51 \text {. DOI= } \\
\text { http://x.doi.org/10.1109/ICIEV.2012.6317487 }\end{array}$ & Bangladesh & $\begin{array}{l}\text { Accessibility in terms of web design generally refers } \\
\text { to facilitating the use of technology for people with } \\
\text { disabilities with any impairment, not matter what its } \\
\text { severity.... } \\
\text { The accessibility can be defined as the quality of a } \\
\text { web site that makes it possible for people to use it - to } \\
\text { find it navigable and understandable - even when } \\
\text { they are working under limiting conditions or } \\
\text { constraints. }\end{array}$ & Henry (2006) & WCAG \\
\hline $\begin{array}{l}\text { Grantham, Grantham and } \\
\text { Powers (2012) }\end{array}$ & $\begin{array}{l}\text { Grantham, J., Grantham, E., \& Powers, D. (2012, } \\
\text { January). Website accessibility: an Australian view. } \\
\text { In Proceedings of the Thirteenth Australasian User } \\
\text { Interface Conference (AUIC 2012). (Melbourne, } \\
\text { Australia, January 202) 126, 21-28 }\end{array}$ & Australia & $\begin{array}{l}\text { Website accessibility refers to the practice of making } \\
\text { websites accessible to all users inclusive of race, } \\
\text { nationality, religion and disability. Website } \\
\text { accessibility includes, but is not limited to, the } \\
\text { communication style of the text as well as the } \\
\text { technical development of the website. }\end{array}$ & & $\begin{array}{l}\text { Section } 508 \\
\text { WCAG }\end{array}$ \\
\hline Márquez et al (2012) & $\begin{array}{l}\text { Márquez, S., Moreno, F., Coret, J., Jiménez, E., } \\
\text { Alcantud, F., and Guarinos, I. 2012. Web } \\
\text { accessibility for visual disabled: An expert } \\
\text { evaluation of the Inclusite® solution. In } \\
\text { Proceedings of the 15th International Conference } \\
\text { on Interactive Collaborative Learning (Villach, } \\
\text { Austria, September } 26 \text { - } 28 \text { 2012) ICL, IEEE, New } \\
\text { York, 1-5. DOI= } \\
\text { http://dx.doi.org/10.1145/2379636.2379657 }\end{array}$ & Spain & $\begin{array}{l}\text { Web accessibility refers to the ability to access web } \\
\text { and its contents for all people regardless of the } \\
\text { disability they have from (physical, cognitive or } \\
\text { sensorial disability), or disabilities arising from the } \\
\text { use contexts (technological or environmental } \\
\text { contexts)" (p 1) }\end{array}$ & & WCAG \\
\hline $\begin{array}{l}\text { Mereuţă, Aupetit and } \\
\text { Slimane (2012) }\end{array}$ & $\begin{array}{l}\text { Mereuţă, A., Aupetit, S., and Slimane, M. } 2012 . \\
\text { Improving web accessibility for dichromat users } \\
\text { through contrast preservation. In Proceedings of the } \\
\text { 13th international conference on Computers } \\
\text { Helping People with Special Needs, (Linz, Austria, } \\
\text { July 11 - 13, 2012). Springer-Verlag, 363-370. } \\
\text { DOI=10.1007/978-3-642-31522-0_55 }\end{array}$ & France & $\begin{array}{l}\text { Web accessibility means that people, disregarding of } \\
\text { their abilities can access the Web. }\end{array}$ & W3C (2011) & \\
\hline $\begin{array}{l}\text { Chevalier, Dommes, and } \\
\text { Martins (2013) }\end{array}$ & $\begin{array}{l}\text { Chevalier, A., Dommes, A., \& Martins, D. (2013). } \\
\text { The effects of ageing and website ergonomic }\end{array}$ & France & $\begin{array}{l}\text { Web accessibility is the inclusive practice of making } \\
\text { websites usable by people of all abilities and }\end{array}$ & & \\
\hline
\end{tabular}




\begin{tabular}{|c|c|c|c|c|}
\hline & $\begin{array}{l}\text { quality on internet information searching. Ageing } \\
\text { and Society, 33(06), 1009-1035. }\end{array}$ & & disabilities. (p1012) & \\
\hline $\begin{array}{l}\text { Calle-Jimenez, Sanchez- } \\
\text { Gordon, and Lujan-Mora } \\
\text { (2014) }\end{array}$ & $\begin{array}{l}\text { Calle-Jimenez, T., Sanchez-Gordon, S. and Lujan- } \\
\text { Mora, S. 2014. Web accessibility evaluation of } \\
\text { massive open online courses on Geographical } \\
\text { Information Systems. In Proceedings of the Global } \\
\text { Engineering Education Conference (EDUCON), } \\
\text { 2014 IEEE (pp. 680-686). IEEE. }\end{array}$ & $\begin{array}{l}\text { Ecuador } \\
\text { Spain }\end{array}$ & $\begin{array}{l}\text { Web accessibility means that persons with disabilities } \\
\text { can use the web on an equal basis with others. (p680) }\end{array}$ & WCAG \\
\hline $\begin{array}{l}\text { Horton and Quesenbery } \\
(2014)\end{array}$ & $\begin{array}{l}\text { Horton, S. and Quesenbery, W. 2014. A web for } \\
\text { everyone: Designing accessible user experiences. } \\
\text { Rosenfeld Media, New York. }\end{array}$ & USA & $\begin{array}{l}\ldots \text { how easily and effectively a product or service can } \\
\text { be accessed and used ... good accessibility is } \\
\text { designed for the full range of capabilities, as well as } \\
\text { for the context of use or environmental constraints. } \\
\text { (p3) }\end{array}$ & WCAG \\
\hline Modesto and Ferreira (2014) & 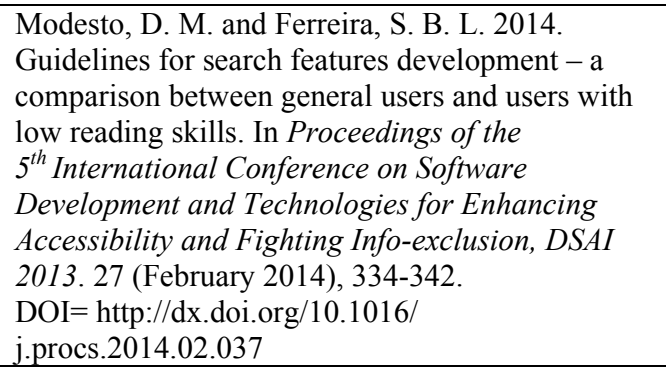 & Brazil & $\begin{array}{l}\text { Web Accessibility is the use of Internet resources and } \\
\text { access to information without barriers, regardless of } \\
\text { cognitive, perceptual or physical capacities of a } \\
\text { person. (p 335) }\end{array}$ & Henry (2007) \\
\hline Park and Lim (2014) & $\begin{array}{l}\text { Park, E. J., \& Lim, H. (2014). A Study on the } \\
\text { Evaluation of the Web Accessibility of a Domestic } \\
\text { General Shopping Site with a High Number of } \\
\text { Visits: Focusing on the Attributes of Alternative } \\
\text { Texts with< img > Tags. Advanced Science and } \\
\text { Technology Letters. } 67,17-20 \text {. DOI } \\
=\text { http://dx.doi.org/10.14257/astl.2014.67.05 }\end{array}$ & Korea & $\begin{array}{l}\text { Web accessibility means that everyone can benefit } \\
\text { from all available information services, regardless of } \\
\text { disabilities. } \\
\text { It refers to equitable access to services offered on } \\
\text { web sites, regardless of a person's physical health or } \\
\text { geographic location. (p17) }\end{array}$ & \\
\hline $\begin{array}{l}\text { Ramesh Babu and Chandra } \\
\text { Sekharaiah (2014) }\end{array}$ & $\begin{array}{l}\text { Ramesh B. J. and Chandra Sekharaiah, K. 2014. A } \\
\text { panorama of web accessibility. International } \\
\text { Journal Of Computer Science and Mobile } \\
\text { Computing (IJCSMC), 3(8) (August 2014), 311- } \\
\text { 317. }\end{array}$ & India & $\begin{array}{l}\text { "Web accessibility refers to enabling the differently } \\
\text { abled people to use the Web. More specifically, it is } \\
\text { about enabling the DAP to perceive, understand, } \\
\text { navigate, and interact with the Web" (p }\end{array}$ & $\begin{array}{l}\text { Henry (2008) } \\
\text { WCAG }\end{array}$ \\
\hline
\end{tabular}

